\title{
Michel Jeanneret, Eros rebelle. Littérature et dissidence à l'âge classique
}

\section{Chiara Rolla}

\section{(2) OpenEdition}

1 Journals

\section{Edizione digitale}

URL: https://journals.openedition.org/studifrancesi/40587

DOI: 10.4000/studifrancesi.40587

ISSN: 2421-5856

\section{Editore}

Rosenberg \& Sellier

\section{Edizione cartacea}

Data di pubblicazione: 1 juillet 2004

Paginazione: 180

ISSN: 0039-2944

\section{Notizia bibliografica digitale}

Chiara Rolla, «Michel Jeanneret, Eros rebelle. Littérature et dissidence à l'âge classique», Studi Francesi

[Online], 142 (XLVIII | I) | 2004, online dal 30 novembre 2015, consultato il 09 septembre 2021. URL: http://journals.openedition.org/studifrancesi/40587; DOI: https://doi.org/10.4000/studifrancesi. 40587

Questo documento è stato generato automaticamente il 9 septembre 2021.

\section{(c) (1)}

Studi Francesi è distribuita con Licenza Creative Commons Attribuzione - Non commerciale - Non opere derivate 4.0 Internazionale. 


\title{
Michel Jeanneret, Eros rebelle. Littérature et dissidence à l'âge classique
}

\author{
Chiara Rolla
}

\section{NOTIZIA}

MICHEL JEANNERET, Eros rebelle. Littérature et dissidence à l'âge classique, Paris, Seuil, 2003, pp. 331.

1 È un XVII secolo diverso quello ricostruito da Michel Jeanneret in un volume che si propone come una «promenade dans quelques quartiers malfamés du Grand Siècle» (p. 15). Non dunque l'età delle certezze e degli equilibri, bensì un'epoca che sotto un velo di perbenismo nasconderebbe «des corps et des esprits en révolte» (quarta di copertina). Quella rievocata dall'A. è dunque una letteratura per lungo tempo censurata, «textes orduriers» che, secondo Jeanneret, generazioni di «dixseptiémistes» avrebbero trascurato per non attentare alla dignità del Grand Siècle. Partendo dal XVI secolo con Marot, Ronsard, Louise Labé, per giungere al Seicento passando per Théophile, Sorel, Béroalde de Verville, il Cid di Corneille e il Dom Juan di Molière - senza mai però dimenticare autori e opere minori - Jeanneret dimostra come «le choix de l'érotisme [...] se donne donc à lire comme un acte d'insubordination, un geste de rébellion intellectuelle et politique» (p. 17). In questi scritti così particolari per loro natura si annuncia dunque quel movimento che, nel XVIII secolo, attraverso il romanzo pornografico e libertino minerà seriamente il potere politico, destabilizzandolo definitivamente. 